Association for Information Systems AIS Electronic Library (AISeL)

GlobDev 2013

Proceedings Annual Workshop of the AIS Special Interest Group for ICT in Global Development

$12-14-2013$

\title{
Assessing the Social Development Potential of Impact Sourcing
}

Fareesa Malik

University of Manchester

Brian Nicholson

University of Manchester

Sharon Morgan

University of Manchester

Follow this and additional works at: http://aisel.aisnet.org/globdev2013

\section{Recommended Citation}

Malik, Fareesa; Nicholson, Brian; and Morgan, Sharon, "Assessing the Social Development Potential of Impact Sourcing" (2013). GlobDev 2013. 4.

http://aisel.aisnet.org/globdev2013/4 


\title{
Assessing the Social Development Potential of Impact Sourcing
}

\author{
Fareesa Malik*, Brian Nicholson*, and Sharon Morgan** \\ *Manchester Business School, University of Manchester UK \\ ** Institute for Development Policy and Management, University of Manchester UK
}

Paper Category: Research Paper 


\title{
Assessing the Social Development Potential of Impact Sourcing
}

Paper Category: Research Paper

\begin{abstract}
Impact Sourcing is an emerging sub-field of global Information Technology (IT) and business Process Outsourcing (BPO) rooted in the concept of business and social development coexistence (Falck \& Heblich, 2007; Porter \& Kramer, 2011). It claims to create employment opportunities through Information Communications Technology (ICT) outsourcing for marginalized people living in areas of limited employment opportunities (The Monitor Group, 2011).

This paper reports on a multidisciplinary research project, linking Information Systems, Corporate Social Responsibility (CSR), ICT for Development (ICT4D) and the Development literature. The primary research objective is to assess the social development impacts of a commercial outsourcing organization which practices Impact Sourcing as its CSR to provide employment opportunities to marginalized rural women through ICT. To achieve this objective, the research draws on Amartya Sen's Capability Approach (Sen, 1999) from the development literature as a guiding framework. Social development impacts of Impact Sourcing are analysed in terms of enabled capabilities of marginalized outsourcing employees.
\end{abstract}

Keywords: Impact Sourcing; CSR; ICT for Development (ICT4D)

\section{INTRODUCTION}

This paper investigates the social development impact of Impact Sourcing, an emerging sub-field of global Information Technology (IT) and Business Process Outsourcing (BPO). Proponents of Impact Sourcing claim that it can create outsourcing employment opportunities through Information Communications Technology (ICT) for marginalized people living in areas of poor employment opportunities (The Monitor Group, 2011). Impact Sourcing is a relatively new field 
with intense research potential and limited research literature. Most of the expansive global outsourcing academic literature is focused on the various dimensions of the management of commercial outsourcing (for a comprehensive review see Lacity et al., 2010 and Lacity et al., 2011).

There is a paucity of literature that focuses on social development impact in ITO/BPO. This study identifies social development impact as the potential and achieved capabilities of marginalized outsourcing employees. There is a nascent literature on social development through IT and BPO initiatives in commercial relationships (Babin \& Nicholson, 2009; Carmel \& Lacity, 2013; Lacity et al., 2011; Madon \& Sharanappa, 2013) and public sector driven social development projects (Heeks \& Arun, 2010).

This paper contributes to the IT/BPO social development literature and specifically focuses on the social development impact of commercial and for profit IT and BPO. The overarching research question guiding our inquiry is:

- How are social development benefits realized in a for-profit commercial IT / BPO Impact Sourcing arrangement?

The empirical research concerns a case study of outsourcing employees and assesses the impact on their lives where "impact" is defined as "positive and negative, primary and secondary longterm effects produced by a development intervention, directly or indirectly, intended or unintended" (OECD-DAC, 2002, p.24). To assess the social development impact we use Sen's Capability framework (1999) as an analytical tool.

The paper is organised as follows: the literature review is in the next section followed by the conceptual framework. Research methodology is presented in section four. We present the research findings in section five and the final section focuses on the research contribution.

\section{LITERATURE REVIEW}

Outsourcing is a process of sending work to an external organization (the service provider) that was previously undertaken within the client's organization (Beaumont \& Sohal, 2004; Kishore et al., 2003). The main justification for ITO and BPO is to focus on core capabilities and obtain high quality services at low cost from outsourcing service providers (Beaumont \& Sohal, 2004; 
Lacity et al., 2010; Lacity et al., 2011). Impact sourcing combines this commercial focus with a development agenda. Carmel and Lacity $(2013$, p5) define Impact Sourcing as:

" a practice of hiring and training marginalized individuals to provide information technology, business process, or other digitally enabled services who normally would have few opportunities for good employment”.

The monitor Group (2011) defines Impact Sourcing as an outsourcing practice which focuses on creating employment for people who live at the Bottom of Pyramid (BoP) which is the largest socio-economic marginalized group of 4 billion people who live on less than $2 \$$ per day (Prahalad \& Hart, 2002). Accenture (2012) broadens the definition from BoP to "marginalized individuals" in low employment areas. Their definition of "marginalized" is not restricted to income; people may be marginalized because of race, religion, gender, sexual orientation, disability, location or any other criteria (Carmel and Lacity, 2013).

Complex IT outsourcing jobs, for example software design, development and testing can be performed through Impact Sourcing (Accenture, 2012). Recent studies show that most of the work tends to be labour intensive and of the least-technical of ICT related outsourcing tasks which can be learned relatively easily. Examples include call centre, support helpdesk, data entry, voice and data transcription, data conversion, and online sales (Accenture, 2012; Heeks \& Arun, 2010; Madon \& Sharanappa, 2013).

Practitioner industry reports (Monitor Group, 2011; Accenture, 2012) claim Impact Sourcing offers a 'win-win strategy' (Falck \& Heblich, 2007) for the outsourcing service providers and clients in terms of offering lower costs to clients typical of BPO/ITO. Additionally the outsourcing service providers can obtain the cost saving advantage of employing marginalized individuals with relatively low operational cost and employee attrition rate. Many of the major centres for ITO/BPO in India (Bangalore, Mumbai, Delhi) have very high rates of staff attrition. The claim of proponents of impact sourcing is that marginalized people (people with limited education, no work experience, or belonging to the communities of low employment opportunities) may be trained to perform outsourced tasks with can improve their income and skills (Accenture, 2012; The Monitor Group, 2011). However, there is a gap in the literature as the evidence from practitioner reports tends to focus more on the first 'win' by capturing the 
benefit to outsourcing service providers'. The claimed second 'win' has yet to be fully explored by assessing the social development impact for marginalized outsourcing employees.

Another related concept of Impact Sourcing is Social Outsourcing or Social IT Outsourcing (Heeks \& Arun, 2010), where Social Outsourcing is defined as, "contracting out the provision of goods or services to a social enterprise" (ibid, p.442). Heeks and Arun (2010) studied Kudumbashree, a social outsourcing project of an Indian state government. The initiative supports poor rural Indian women in Kerala to establish social ICT enterprises with the help of government grants and bank loans, with Government acting as an intermediary to provide public sector outsourcing projects for these ICT social enterprises (Heeks \& Arun, 2010). Madon and Sharanappa (2013) also explored Social IT Outsourcing, identifying the balance between market orientation and social development thus embracing social enterprise concepts in outsourcing. In a case study of the IT outsourcing activity of KGVK, a nonprofit arm of KGVK Rural Enterprises, they considered the development objectives of the IT outsourcing enterprise with respect to the local community needs.

But how do we assess social development impact? Carmel and Lacity (2013) claim that a major focus of research in this area to date is on Impact Sourcing service providers and their clients, rather than their employees, and suggest that analysis and assessment of the social development impact may be best explored with the help of development literature. This paper responds to this research gap and evaluates the social development impact of a for-profit commercial outsourcing service provider by using Amartya Sen's Capability framework (Sen, 1985; Sen, 1987; Sen, 1999).

\section{CONCEPTUAL FRAMEWORK}

Sen's Capability framework offers a set of conceptual tools to assess change in society in terms of individual well-being and social development (Sen, 1999; Robeyns, 2005). The Capability framework is focused on the achievement of individual capabilities, and Sen has argued for developing policies and projects which improve individual capabilities so that people have freedom to live the lives they value (Sen, 1999). Scholars have proposed different approaches to operationalize the Capability framework (Alkire, 2007; Frediani, 2010; Nussbaum, 2000; 
Robeyns, 2005). Here we use Robeyns's (2005) interpretation as the guiding framework for this research due to its wide empirical application and clarity.

Focusing on the key development impact of being employed by the Impact Sourcing organisation, this study takes into account three salient elements of Sen's Capability framework: Conversion Factors, Resources (capabilities input) and Capabilities.

- Capabilities include a set of potential and achieved functionings which the Impact Sourcing initiative may have enabled in marginalized outsourcing employees.

- Conversion Factors include all elements which may enable or restrict an individual from being employed, for example, lack of skills, lack of resources, cultural constraints, family support, etc.

- Resources include all tangible or intangible resources which act as capability inputs and opportunities provided by the outsourcing service provider to extend capabilities or to minimize the effect of restrictive conversion factors. For example, provision of training, a conducive work environment, provision of internet and computers etc.

\section{METHODOLOGY}

The paper is based on an interpretive case study methodology to explore the issue in its natural setting (Benbasat et al., 1987; Walsham, 2006). Qualitative research methods for data collection and analysis were used. Primary data was collected through semi structured interviews with company employees in the Harva outsourcing centre located in Tikli village, near district Gurgaon in Haryana State, India. Due to practical constraints interviews were conducted through Skype and telephone. Robeyn's (2005) operationalization of the Capability framework was used as a guiding framework to structure interview questions but the semi-structured interviews were exploratory in nature and allowed interviewees to deviate from the topics without constraint. We asked questions to gain employee perceptions around the topics of outsourcing job experience, usability of ICT, enabling and restricting factors of doing IT/BP outsourcing jobs, availability of tangible and intangible resources to support employment, and changes in capabilities (both negative or positive) as a result of their engagement with Harva. Altogether 10 interviews of varying length, 30 minutes to 75 minutes, were undertaken with company employees belonging 
to different levels: high level management, middle level management, outsourcing employees and trainees. Secondary data was also collected through the company's web-site, press releases and other reports ${ }^{1}$.

The research employed purposive sampling technique to establish a good connection between research questions and data collection (Symon \& Casell, 2012). The respondent sample was diverse in terms of working experience, ranging from the most senior employees with three years of experience since the company's inception. The most junior trainees had joined Harva in the last two months. Since Harva is a women-based outsourcing service provider, the interviewees were all women of age 18 to 32 years who did not attend university and have an average educational level of 12 th grade.

Respondents were given complete freedom of expression to speak in a language they feel comfortable, as the interviewer and first author (a female Pakistani national) can converse in Hindi and in English. All interviews were recorded, transcribed and translated into English by the interviewer. Secondary data (reports, web-site, and press releases) were already in English and did not require translation. Thematic data analysis techniques were used to analyse the data, drawing on Robeyn's (2005) operationalization of Sen's Capability framework. Nvivo 9 software was used to organize and manage data. The initial process of coding was to generate some basic codes relevant to the research questions and objectives (Auerbach \& Silverstein, 2003; Miles \& Huberman, 1994). The three main elements of Sen's framework, 'Conversion Factors', 'Resources', and 'Capabilities' were defined as parent codes in the software. These three parent codes acted as a basic structure for data analysis. Interviews were analysed on an individual basis with each transcript analysed thoroughly for identification of further codes under these three themes. Sub-categories were also defined by grouping similar codes. The process was iterative in nature and new codes and sub-codes were added, deleted or merged in each iteration.

${ }^{1}$ http://www.harva.co.in/

http://articles.economictimes.indiatimes.com/2010-08-04/news/27617594_1 rural-bposbusiness-process-outsourcing-harva http://www.indiatogether.org/2010/may/wom-bpojobs.htm 
A total of 63 codes were identified after all interviews had been analysed, under 12 key categories. Although the coding process was carefully focused on the research problem and questions, it was completely open to emerging concepts and new themes related to the research (Lincoln \& Guba, 1985).

\section{Case Description}

Harva is an Indian for-profit commercial outsourcing service provider that was established in 2010 and opened its first rural outsourcing centre in the Indian village of Tikli in Haryana. Tikli is an agrarian village $42.6 \mathrm{~km}$ north of India's capital New Delhi, with a population of about 15,034 persons living in around 1,390 households. Located in this farming community are employees of a rural BPO run by Harva, as a start-up. Along with typical business objectives, e.g profitability, Harva also has development objectives as part of its CSR: to create an ICTproducer market across India by tapping the rural outsourcing talent. This differs from most social and technological inclusion initiatives that cover rural and remote areas to tap their large ICT-consumer market (for example, expansion of ICT services, mobile networks, micro finance) (Bhatnagar \& Schware, 2000; Harris, 2004). Under its slogan 'Harnessing the Value' Harva provides free basic ICT and outsourcing job training to rural women. ICT training includes basic computer operating skills, Microsoft Office and internet. English language training and basic outsourcing job training such as data entry are also provided. After initial training, women are offered jobs in the centre which is located close to their village. To date Harva has opened its outsourcing centres in fourteen states of India and has employed over 400 rural women.

\section{FINDINGS}

Research findings are presented in three broad categories representing the three components of the frame: conversion factors, resources, and capabilities.

\section{Conversion Factors}

Conversion factors include all those elements that may enable/restrict individual opportunities or choices (capabilities) of working as an outsourcing employee. They are divided into individual conversion factors, social conversion factors, environmental conversion factors and technology conversion factors. The summary of all conversion factors is presented in table 1 . 
Table 1 Conversion Factors

\begin{tabular}{|c|c|c|}
\hline Category & Sub-Category & Code \\
\hline Conversion & \multirow[t]{3}{*}{$\begin{array}{l}\text { Enabling individual conversion } \\
\text { factors }\end{array}$} & $\begin{array}{l}\text { Personal will to support family } \\
\text { financially }\end{array}$ \\
\hline \multirow{5}{*}{$\begin{array}{l}\text { Individual } \\
\text { Factor }\end{array}$} & & Motivation for learning \\
\hline & & Self-belief \\
\hline & \multirow{3}{*}{$\begin{array}{l}\text { Restrictive } \\
\text { conversion factors }\end{array}$} & Lack of confidence \\
\hline & & Technical incompetency \\
\hline & & Language incompetency \\
\hline \multirow[t]{6}{*}{$\begin{array}{l}\text { Social } \\
\text { Factors }\end{array}$} & \multirow[t]{2}{*}{$\begin{array}{l}\text { Enabling social } \\
\text { factors }\end{array}$} & $\begin{array}{l}\text { Awareness about importance of } \\
\text { ICT (Technology Image) }\end{array}$ \\
\hline & & Family support and encouragement \\
\hline & \multirow{4}{*}{$\begin{array}{l}\text { Restrictive social conversion } \\
\text { factors }\end{array}$} & Culture and norms \\
\hline & & Gender inequity \\
\hline & & Family opposition \\
\hline & & Poor social standing \\
\hline \multirow{2}{*}{$\begin{array}{l}\text { Environmental } \\
\text { Conversion Factor }\end{array}$} & \multirow{2}{*}{$\begin{array}{l}\text { Restrictive environment } \\
\text { conversation factors }\end{array}$} & Distance and travel Issues \\
\hline & & Power shortage \\
\hline \multirow[t]{5}{*}{$\begin{array}{l}\text { Technology } \\
\text { Conversion Factors }\end{array}$} & $\begin{array}{l}\text { Enabling technology } \\
\text { conversion factors }\end{array}$ & $\begin{array}{l}\text { Awareness about the importance of } \\
\text { ICT }\end{array}$ \\
\hline & \multirow{4}{*}{$\begin{array}{l}\text { Restrictive technology } \\
\text { conversion factors }\end{array}$} & Fear of technology \\
\hline & & Unavailability of computers \\
\hline & & Unavailability of Internet \\
\hline & & Expensive smart phones \\
\hline
\end{tabular}

\section{Individual Conversion Factor}

The respondents identified both enabling and restrictive individual conversion factors during interviews. We categorize enabling factors as "self-belief", "motivation for learning", and "personal will to financially support their families". Self-belief was a major individual factor, which helped employees realize that if they try they can learn and get a white-collar job. They wanted to learn and increase their ICT and professional skills. The inner drive, motivation for learning and self-motivation are primary individual factors which help them to embrace the 
existing ICT training and outsourcing employment opportunities. They were willing to come to the outsourcing centre for training and work. If they didn't have self-motivation and willingness then it would be impossible to bring them to the learning and earning opportunities provided by Harva. One outsourcing employees stated:

"I had believed in myself that I could do something and I will learn this all." (Respondent 5)

Financial conditions for rural women were not very good (Fan et al., 2000). These women wanted to support their families by contributing financially for their well-being. They realized that if they can get some decent earning opportunities then their family's financial condition could become better. Their inner will to contribute financially is another individual enabling factor which encouraged them to join Harva:

"They announced free computer training for women leading to the outsourcing work. I came to know that less-educated women of ten-to twelve grade educational level who are staying at home spending time in house chore and dung cleaning could also get jobs. Then I thought, lets go out and earn money to support my family." (Respondent 3)

However, there were restrictive factors. Firstly, the majority of the outsourcing employees had not seen a computer before in their life, and they interpreted their lack of skills to operate computers as their inappropriateness for work:

"Initially I had a fear that I could not do the job because I didn't know computers." (Respondent 6)

Another individual restrictive conversion factor was English language incompetency. They thought that as they could not speak and understand English properly, it would be almost impossible for them to learn computing and get an office job. Computers and the notion of women working in offices were both quite unusual for them. Rural women had never worked in offices before Harva opened its outsourcing centre in the village. It was difficult for them to be confident enough to go out from their houses to work. An outsourcing employee talked of her lack of confidence:

"I was worried about my English and confidence, but here all my seniors have helped me and supported me a lot." (Respondent 4) 


\section{Social Conversion Factors}

Social norms and cultural factors had significant influence on the rural women's decision to work in the Harva centre. India is regarded by many scholars as a patriarchal society (Chakravarti, 1993). Patriarchy is a social system and culture of male dominance (Walby, 1990). Generally, village cultural norms dictated that women do not work in offices. However, some respondents were obtaining ICT training and working as outsourcing employees because of family encouragement and support. These women and their family members are well aware of the importance of ICT (Cecchini \& Scott, 2003). One trainee commented:

"My family wanted me to learn computers so that I could be employable. Then I thought, OK. Let's learn computers and come in this line." (Respondent 10)

At the same time other respondents faced opposition from their families before joining. One respondent shared a bad experience of her friend who joined the office along with her but had to leave the job because of adverse social and family pressure:

"The husband of a woman, who had joined for computer training with me, forbade her to learn and work in the office. But she wanted to learn ICT and work here so she continued coming here. Then he became abusive because he could not tolerate that she was earning. He insisted that he would earn himself. She could not solve her domestic issues and left during training. It was an exceptional case, the majority of women here are supported by their family." (Respondent 3 )

Employees commented that working in an office and being employed for a white-collar job was something new in that culture:

"I did not face serious challenges, only my mother-in-law had some objections that 'what will you do by doing a job? There is lots of work at home and in the fields how could it be managed?' But my husband supported me and I started working now everyone is happy." (Respondent 3)

We could not find any particular reason behind this contradictory finding, all respondents belonged to the same area, sharing the same culture, traditions and social values. Initial findings reflected that the difference could be explained by marital status; the unmarried outsourcing employees faced less social pressure and obtained permission to work from their parents more easily. Married women by contrast were expected to manage the home and children. After more interviews with married outsourcing employees, married women expressed a greater level of 
commitment to their jobs. For some, their husbands and in-laws supported them by looking after the children in their absence because they were perceived as working for the betterment of their family.

"I told my husband that I want to do job. He said it is fine for me. If you feel this job is good for you then go ahead." (Respondent 4)

Another explanation is that some families in the village are quicker in accepting positive change whereas the process of social acceptance was slow in other families.

\section{Environmental Conversion Factors}

Restrictive conversion factors imposed by the commute to distant areas is a major challenge which rural women face (Madon \& Sharanappa, 2013). It was very difficult for the rural women to travel to the nearby city for ICT training due to slow and unreliable public transportation from the village. Additionally, social norms restricting women travelling alone on buses was another restricting factor:

"If I would have to go outside the village for job and I will ask my parents for permission then they will refuse my request completely. " (Respondent 9)

Clearly, distance and travel issues are considerable environmental conversion factors which had restricted women's ICT training and outsourcing employability.

Power outage was another environmental conversion factor which comes out during investigation as restricting ICT capabilities. Most of the time, there was no electricity in the village or the power was too low to operate electronic devices Many respondents had never seen a computer before joining Harva because they did not have it at their home or neighborhood. Access to capital and power constraints had discouraged the availability of electronic devices and thus their usage.

\section{Technology Conversion Factors}

During this study, a new conversion factor adding to Robeyn's (2005) frame emerged from the data. Interviewees identified technology as a separate category under conversion factors with both enabler and restrictive features. The parents of some respondents had realized that their daughters should learn computing along with basic education to improve her employability. 
"My father wanted me to study and my mother insisted that I have to learn computers so that I can start my professional life in parallel.” (Respondent 10)

Generally, women outsourcing employees and their families had good awareness about the importance of ICT - a major enabling factor to encourage women for ICT training and outsourcing employment. They perceived that computer-operating skills are necessary to obtain white-collar employment. One trainee shared her view:

"Computer is a need of this world and I had realized it. I knew that I have to learn it to be competitive. When we will apply for any job, people will ask: 'do you know computer'?” (Respondent 7)

However, fear of using technology and the lack of availability of computers, internet and smart phones at home emerged as a restrictive technology conversion factor. One outsourcing employee commented:

"I did not know how to use internet and computers. I did use mobile just for receiving and making calls but did not know anything about its other functionality. ”(Respondent 8)

Some respondents had never seen computers in their life before; some had never used the internet, as one trainee expressed:

"I did not know anything; I did not know there is something called internet. Now, my knowledge has increased." (Respondent 9)

Mobile phones however were common and all respondents had used them even if they did not have their personal mobile phone. Almost all employees use mobile phones to communicate with their family and they considered it a necessity rather than a luxury. However, the majority of them still do not have access to a computer and internet at their homes and they use them in the outsourcing centre only. Internet facilities were not available in the village which restricts the usability of the internet. The CEO of Harva mentioned about ICT resource challenges:

“Basic challenges are power and internet. These challenges are primary." (Respondent 1)

Very few respondents were using internet on their mobile, which included higher and middle level management and most senior outsourcing employees due to the extra cost of mobile internet and smart phones. 
Respondents shared their initial experience of learning technology. They were scared of using computers and the fear of breaking the computer or keyboard was a major problem which made them reluctant initially to touch them:

"The problem I faced initially was a real fear to operate the computer. As I did not operate it before so I was scared that something would go wrong or maybe I would break it. What if the window malfunctions?" (Respondent 4)

As this technology was not available in the domestic context employees had no initial familiarity.

\section{Resources (Capabilities input)}

In this section we will describe what kind of resources the Impact Sourcing organization has provided to their employees. We will also discuss the impact of these resources on conversion factors, particularly, the effect on restrictive conversion factors. These resources are categorized into tangible and intangible resources and taken as capability inputs.

Table 2 Resources

\begin{tabular}{|c|c|c|}
\hline Category & Sub-Category & Codes \\
\hline \multirow[t]{5}{*}{ Tangible Resources } & Office facilities & $\begin{array}{l}\text { Closely located office } \\
\text { building }\end{array}$ \\
\hline & & Office furniture \\
\hline & Provision of ICT equipment & $\begin{array}{l}\text { Continuous power supply } \\
\text { through generator }\end{array}$ \\
\hline & & $\begin{array}{l}\text { Good internet connection } \\
\text { Computers }\end{array}$ \\
\hline & & Smart phones \\
\hline \multirow[t]{5}{*}{ Intangible Resources } & Colleagues' support & Peer encouragement \\
\hline & & Professional help and support \\
\hline & Learning and working environment & $\begin{array}{l}\text { Flexible learning and } \\
\text { working hours }\end{array}$ \\
\hline & & Cultural acceptance \\
\hline & & Allowed to retain their \\
\hline
\end{tabular}


traditional attire and norms

Provision of training

Basic ICT training

English language training

BPO skills training

ITO skills training

Soft skills and professional training

\section{Tangible Resources}

Physical working resources and ICT equipment are tangible resources which have been provided by Harva. We have discussed under environmental conversion factors that travel to distant areas for learning and earning was a major hurdle for rural women. Harva has opened its outsourcing centre very close to the villages where women can walk to work. One nineteen year old trainee commented about the importance of this proximity for family approval:

"This is the first time I go out of the house for work. My parents and grandparents are very satisfied now because the centre is nearby to my house and I am working with local and known people. They think I am quite young and immature and it is safe to come here. I arrive here walking with friends. " (Respondent 9)

The outsourcing centre was using a generator for maintaining a continuous supply of electricity because of power outages. Outsourcing employees were provided with individual computers and high speed internet during training and after training to perform their outsourcing tasks. In their free time, these women could use these facilities for personal matters, for example, social media, or internet browsing or entertainment. One outsourcing employee told us that:

"I don't have internet and computer at home but I use internet at centre daily when I get free time." (Respondent 4)

The outsourcing centre also had some smart phones which were given to the employees for mobile applications testing. These phones were not given for personal use but so that employees would get some hands-on experience to use the latest mobile phones and gain knowledge about 
Android technology. Here we see examples of resources provision enabling the women to build social capital (Bourdieu, 1986; Woolcock, 2001) for their own development.

\section{Intangible Resources}

Colleagues' support, comfortable learning and working environment, and provision of training are the intangible resources which were provided by the centre. Rural women were obtaining continuous encouragement and support from their peers and higher level management. During their training phase they received continuous support if they started losing confidence. One outsourcing employee shared her experience:

"I discussed my concerns with my trainer that I don't think I could learn English but he said, "No, have trust and confidence on yourself; you can learn it". (Respondent 3)

When they started jobs after training, everyone in the centre tried to help each other out in doing work. The company management gave extra attention to those employees who could not perform well. Instead of discouraging them, collective efforts from colleagues were used to bring those employees to the required level of quality and throughput.

"I am giving credit to my centre manager. She encourages me a lot and continuously reminding me that I can do anything and I should try my level best." (Respondent 4)

The women had options to work any shift as the centre provides flexible hours. Evening shift training was provided to provide female students with free computer training after their school and college hours. Outsourcing employees were getting paid according to quantity of work and there is no restriction of fixed hours to retain their jobs. This flexibility encourages rural women to learn as well as to earn money.

Respondents believed that they had experienced no favoritism and that all employees are treated equally. They are more comfortable with the people they know from the village; it is easier for them to learn from someone like them (from same location, background). As a trainee commented:

"I am belonging to the village. I could not adjust and learn in a modern high class computer centre in the city directly, I might feel some inferiority complex. But this centre is in village and most of the trainers are from us who initially learn and then transmit knowledge. We speak same 
language so it is in my comfort zone. The environment is very conducive and comfortable that's why I like to come here to learn things and do the job." (Respondent 9)

As Harva was the first Impact Sourcing organization which had established its outsourcing centre in the village, company policies did not force women to change their attire. Some at Harva believe that the women's outsourcing employment had gradually gained acceptance in the community because it did not conflict with their cultural and religious norms and values. Rural women have the freedom to maintain their cultural or religious identity while working at Harva. The CEO commented:

"The women in some area usually wear Ghongat (Veil to cover their faces) that's why they were not allowed to step out from their homes for work. We did not ask them to change their outlook for work. ” (Respondent 1)

Respondents had no university degrees, professional training or any kind of professional experience before joining Harva. The training represents resources which the Impact Sourcing organization has provided to rural women to overcome their lack of language and technical competence thus overcoming individual restrictive conversion factors. All rural women were offered free computer training initially and those who were willing to learn could come to the outsourcing centre in evening shifts. One woman shared her experience of joining computer training and the necessity for family approval:

"I had to convince my family that I am getting computer knowledge without spending any money so they did not have any objection." (Respondent 7)

Basic English language training was also part of the training. An outsourcing employee mentioned about it:

"It was very hard to do work in English and especially to learn computer which is in English. But they provided us a teacher who taught us English for one month. Then things became easier for me." (Respondent 3)

Here once again we see wider potential impact of such resource provision for building social capital. 


\section{Capabilities \{Sets of Potential and Achieved Capabilities\}}

Capabilities are sets of potential and achieved functioning which outsourcing employees are able to achieve as a result of resources provided by the Impact Sourcing organization.

We have identified six types of capabilities from the data set: economic capabilities, educational capabilities, individual capabilities, professional capabilities and ICT usability capabilities. These capabilities include both potential and achieved capabilities because we present the aggregated findings of all respondents. For example capability of supporting higher education under educational capabilities is a potential capability of all outsourcing employees but few of them had chosen it as an achieved capability by continuing their higher study. Table 3 summarises the findings.

Table 3 Set of Potential and Achieved Capabilities

\begin{tabular}{ll}
\hline Category & Code \\
Economic Capabilities & Spending on daily expenses \\
& Investment capabilities \\
& Saving capabilities \\
& Spending on education \\
& Spending on health \\
Empowerment & Social Empowerment \\
& Financial Empowerment \\
& Technology Empowerment \\
Improved knowledge \\
Supporting higher education \\
ICT education \\
Decision-making power \\
Improved communication skills \\
Improved self confidence \\
Multitasking and management skills \\
Perception about the world \\
Personal development \\
Employability \\
Professionalism \\
\hline
\end{tabular}




\begin{tabular}{ll}
\hline & Awareness of client expectations of quality management \\
Punctuality & Teamwork \\
Educt Usability Capabilities & Knowledge of sources of information \\
& Performing outsourcing tasks \\
& Submitting tasks to head office \\
& Socialization and networking \\
& Entertainment \\
Communication and keeping in touch with family & \\
\hline
\end{tabular}

\section{Economic Capabilities}

Working as an outsourcing employee had a major influence on respondents' economic capabilities. Respondents told us that their job supported them financially and now they can spend their earning on different expenses. Respondents spent their earned income to meet every day expenses and to buy daily groceries, to invest in personal and children's insurance, to save in banks, to spend on personal and children's education and also on their children's health. We realized that women were not only bearing their everyday expenses but they were taking saving decisions for the future. One outsourcing employee stated:

"I also use (the salary) to do some savings. After household daily expenses, I am able to spend it on insurance of myself and my daughter." (Respondent 3)

There were two different spending approaches between married and unmarried employees. The un-married group tend to spend their earned income to bear their own expenses, education and to support their families:

"I spent my money to buy books and I have passed twelve grades." (Respondent 5)

The unmarried were also interested in saving some portion of their earned money for their wedding expenses or planning to spend on higher education.

"From last three years I am saving my salary in the bank. I will use it meet my wedding expenses." (Respondent 7) 
Married outsourcing employees are more focused toward spending their income on health and their children's future education as well as household expenditures. One respondent told us that she did not spend her money on everyday expense and saved it for major expenses, for example, to buy some expensive household item if necessary; otherwise she was saving money to take her son to a good private school.

"We are thinking about our son, as he is growing up. We are planning to take him to a good private school which will definitely cost us more. This is the reason we are saving money; we are saving for our son's bright educational future." (Respondent 4)

\section{Educational Capabilities}

The education capabilities which respondents believed had improved after getting this employment included increased knowledge, capability for higher education and ICT education. These outsourcing employees had acquired knowledge about technology and the job market and their perspective of life had changed after becoming outsourcing professionals. They did not know the importance of education and a professional career before, but when they started their job and socialized with colleagues, they exchanged information and knowledge. Their working life had realized the importance of education.

“My knowledge has increased and my confidence has improved." (Respondent 9)

One respondent told us that now she was giving priority to her children's education because she had become aware about its importance for their future. Outsourcing employees and trainees were motivated to continue their education in parallel for a more progressive professional career. Working in the outsourcing centre could help them afford their own educational expenses. One trainee expressed her future wish to continue her education:

"I will do job here after learning computer but I will not leave my education; I will continue it in parallel because I will be able to bear my educational expenses very soon." (Respondent 10)

The outsourcing centre contributed an active part to spread ICT education in that area:

"Now I have full confidence that I can operate computer properly. I use excel for data entry and Gmail for sending emails. In my free time I check my face book and read news." (Respondent 5) 


\section{Empowerment}

Empowerment is interpreted in Sen's Capability framework as a freedom to live a life a person values (Sen, 1999). We found three kinds of empowerment from our data: Social, Financial and Technological. Women felt socially empowered after becoming outsourcing professionals. Their in-laws and husband were more supportive now and were sharing the domestic workload so that they could manage their jobs. Their respect and value in the family had increased.

"I share everything with my husband and now if he faces any problem he takes my advice. I use to guide him what to do and what not to do. He listens to my suggestions. Now the attitude of family and relatives has changed. They know I can do something." (Respondent 4)

Outsourcing employment had made them financially independent. One outsourcing employee told us:

"I don't need to ask my parents for my personal expense, now I can bear them by myself." (Respondent 7)

Apart from self-financial independence, they were capable enough to contribute partially to meet their family expenses:

"I am getting money based on my work. I keep some money for myself and I give the remaining to my family for everyday expense." (Respondent 8)

\section{Personal Capabilities}

Another theme which emerged from the data after analysis is personal capabilities. Our definition of personal capabilities includes all positive changes in individual characteristics after getting employment (Madon \& Sharanappa, 2013). One major change in personality which all outsourcing employees mentioned during interviews was improvement in their communication skills. Women could not communicate properly with new people before; they felt reluctant, shy and sometimes scared. They told us that professional life had given them confidence and enabled them to communicate effectively.

One outsourcing employee said: 
"My speaking power and communication skills have improved. I felt shy, reluctant and inferior while talking with strangers. I can see a major change in my personality, now I am talking to you confidently. "(Respondent 9)

They have gained confidence to speak and communicate properly. One thing which we noticed during interviews was the different levels of self-confidence among the respondents. Senior outsourcing employees who had been working in the outsourcing centre for a long time were very confident in replying to the interview questions in detail, whereas some trainees who recently had started to come to the outsourcing centre for ICT training were shy and preferred nodding their head or gave very short answers, sometimes only 'Yes' and No'. The fact that they were speaking to a stranger and also through Skype technology which was new for them, might be a reason for their attitude, as they were not confident with its use as compared to other senior employees.

Professional life had helped to develop their self-confidence and trust.

"I have got trust and self-confidence that I can do anything now." (Respondent 6)

Female respondents had gained multi-tasking skills. Before starting their professional life they spent all of their time doing household chores. They still had been managing these very well with the job because of self-organization. They managed to complete their home responsibilities before coming to office.

"I used to manage house chores and office work together. If I don't come to office I feel tiredness and boredom because of doing nothing. I have become habitual of multi-tasking and distributing my time." (Respondent 4)

Along with family responsibility they were also concerned about their own appearance and personality and were also enjoying the positive changes in their personalities.

"After joining here, I can see lots of changes in myself. My style of speaking, personality, and communication with people have improved." (Respondent 5)

\section{DISCUSSION}

This paper has added to the limited literature on Impact Sourcing, where BPO business models are used to bring development benefits to marginalized communities. Whereas previous research 
in this arena has focused on either the (BPO) business benefit alone, or on the social development benefit within a non-profit CSR (Madon and Sharanappa 2013) or limited commercial environment (Heeks and Arun 2010;), this research is unique in investigating potential for social development impact while operating under a for profit commercial business model.

The main contribution of this paper is highlighting the restrictive and enabling conversion factors that may influence the overall capabilities of marginalized outsourcing employees. Secondly, how the Impact Sourcing organization may contribute to minimize the effect of restrictive conversion factors and enable capabilities by providing resources. Using interview data of outsourcing employees we have identified tangible and intangible resources provided by the Impact Sourcing organization.

Slavova et al. (2011) discusses weaknesses of the Capability framework for ICT intervention, arguing that there is very limited practical use of the Capability framework for ICT related projects. This study attempts to practically implement Sen's Capability framework to assess the impact of Impact Sourcing. The Capability framework has also been criticized for being overly focused on the individual (Gore, 1997; Stewart, 2005), yet Madon and Sharanappa (2013) use the framework to discuss community impact along with individual capabilities while measuring a social outsourcing initiative. In this research here, although we focus particularly on individual impacts, we can see aspects of wider community impact, for example, when discussing contradictory social conversion factors, such as family support and restrictions from family. We observe the gradual community transformation of cultural acceptance of women working in offices, yet other evidence also hints at the reluctance or limitation in transformation in these gender-based norms. For instance, women are still expected to complete their household responsibilities, as well as now taking on a productive role (Moser, 1993) and the choices they have (or make) regarding further career development (such as moving to a city job) may be constrained by these cultural gender norms. It is a glimpse of Impact Sourcing's impact on the community but consideration of wider level impact of Impact Sourcing on community or institutions is a future research agenda.

Robeyns (2005) identified three categories of conversion factors, personal, social and environmental when operationalizing the Capability framework. During data analysis, we 
identified some novel conversion factors, for example, image and importance of ICT and fear of technology, unavailability of technology etc, which could not fit appropriately in any one of these pre-defined categories. We group these factors under an independent new category of Technology conversion factors. This addition of Technology conversion factors in the Capability framework is another contribution of this study toward customizing it with technology.

\section{LIMITATIONS AND FUTURE WORK}

A number of limitations need to be acknowledged. In this study output capabilities are defined on aggregate level - not all participants have all capabilities mentioned. Hence, the capabilities set includes all possible and achieved capabilities that the particular Impact Sourcing organization may enable for marginalized outsourcing employees. There were two reasons to aggregate all capabilities. First it is unfeasible here to discuss them on an individual level for each respondent; second, our research objective is to evaluate the social development impact of an outsourcing service provider overall when practicing Impact Sourcing. Discussion of potential capabilities and achieved capabilities separately are not a point of consideration in this paper, but would be future research work.

This study attempts to provide initial findings only which we can not broadly generalize. There is a need for more research in different contexts to assess the social development Impact Sourcing providers. Impact Sourcing is a global phenomenon: different country contexts and types of outsourcing service provider should be researched to enrich the theoretical findings.

Until now, Impact Sourcing research is focused on poor communities and rural areas. As we initially have discussed, people may be marginalized because of many other factors, for example, employment opportunities, income, religion, education. Future research work is needed to explore other dimensions of marginalization in different populations to bring richer variety to the findings.

Lastly, our study findings mainly reflect positive aspects. More in-depth case studies and ethnographic research of outsourcing service providers are necessary to highlight deeper challenging impacts. Future work will focus on detailed ethnographic data collection and extended fieldwork in the outsourcing centres to add deeper insight into the impact and capabilities, to unravel further the meanings and aspects of 'empowerment' and agency (Kabeer 
1999) affecting achieved functionings or capabilities, and the more transformational impact that may lead to sustainable development for these communities.

\section{REFERENCES}

Accenture (2012) Exploring the Value Proposition for Impact Sourcing: The Buyer Perspective. Accenture.

Alkire, S., (2007) Choosing dimensions: the Capability Approach and Multidimentional Poverty. Chronic Poverty Research Centre Working Paper 88.

Auerbach, C.F. \& Silverstein, L.B. (2003) Qualitative Data: An Introduction to Coding and Analysis. New York: NYU press.

Avasant (2012) Incentives \& Opportunities for Scaling the "Impact Sourcing" Sector. [Online] Available at: http://www.rockefellerfoundation.org/news/publications/incentives-opportunitiesscaling [Accessed 14 November 2012].

Babin, R. \& Nicholson, B. (2009) Corporate Social and Environmental Responsibility and Global IT Outsourcing. MIS Quarterly Executive, 8(4), pp.203-12.

Beaumont, N. \& Sohal, A. (2004) Outsourcing in Australia. International Journal of Operations \& Production Management, 24(7), pp.688 - 700.

Benbasat, I., Goldstein, D.K. \& Mead, M. (1987) The Case Research Strategy in Studies of Information Systems. MIS Quarterly, pp.369-86.

Bhatnagar, S. \& Schware, a.R. (2000) Information and Communication Technology in Development: Cases from India. Sage Publications Ltd.

Bourdieu, P. (1977). Outline of a Theory of Practice. Cambridge and New York: Cambridge Univ Press;

Carmel, E. \& Lacity, M.C. (2013) The Impact of Impact Sourcing: Framing a Research Agenda. In ICIOS Mannheim. Mannheim, 2013.

Cecchini, S. \& Scott, C. (2003) Can Information and Communications Technology Applications Contribute to Poverty Reduction? Lessons from Rural India. Information Technology for Development, 10(2), pp.73-84.

Chakravarti, U. (1993) Conceptualising Brahmanical Patriarchy in Early India: Gender, Caste, Class and State. Ecomonic and Political Weekly, pp.579-85. 
Falck, O. \& Heblich, S. (2007) Corporate Social Responsibility: Doing Well by Doing Good. Business Horizons, 50(3), pp.247-54.

Fan, S., Hazell, P. \& Thorat, S. (2000) Government Spending, Growth and Poverty in Rural India. American Journal of Agricultural Economics, 82(4), pp. 1038-1051.

Frediani, A.A. (2010) Sen's Capability Approach as a Framework to the Practice of Development. Development in Practice, 20(2), pp.173-87.

Gore, C. (1997) Irreducible Social Goods and the Informational Basis of Amartya Sen's Capability. Journal of International Development, 9(2), pp.235-50.

Harris, R.W. (2004) Information and Communication Technologies for Poverty Allevation. Kuala Lumpur: UNDP.

Heeks, R. \& Arun, S. (2010) Social Outsourcing as a Development Tool: The Impact of Outsourcing IT Services to Women's Social Enterprises in Kerala. Journal of International Development, 22, pp.441-54.

Kabeer, N. (1999) 'Resources, Agency, Achievements: Reflections on the Measurement of Women's Empowerment', in Development and Change, Vol. 30, pp.: 435-464.

Kishore, R. et al. (2003) A Relationship Perspective on IT Outsourcing. Communications of the $A C M, 46(12)$, pp.86-92.

Lacity, M.C., Shaji Khan, A.Y. \& Willcocks, L.P. (2010) A review of the IT Outsourcing Empirical Literature and Future Research Directions. Journal of Information Technology, 25, pp.395-433.

Lacity, M.C., Solomon, S., Yan, A. \& Willcocks, L.P. (2011) Business Process Outsourcing Studies: A Critical Review and Research Direction. Journal of Information Technology, 26, pp.221-58.

Lincoln, Y.S. \& Guba, E.G. (1985) Naturalistic Inquiry. Beverly Hills, CA: Sage Publications.

Madon, S. \& Sharanappa, S. (2013) Social IT Outsourcing and Development: Theorising the Linkage. Information Systems Journal, 1, pp.1-17.

Miles, M.B. \& Huberman, A.M. (1994) Qualitative Data Analysis. 2nd ed. SAGE Pulications.

Moser, C. (1993) Gender Planning and Development. London: Routledge.

Nussbaum, M.C. (2011) Creating Capabilities: the human development approach. London: Harvard University Press.

Nussbaum, M. (2000) Women and Human Development: The Capabilities Approach. Cambridge: Cambridge University Press. 
OECD-DAC (2002) Glossary of Key Terms in Evaluation and Result Based Management. [Online] Available at: http://www.oecd.org/development/peer-reviews/2754804.pdf [Accessed 14 June 2013].

Porter, M.E. \& Kramer, M.R. (2011) Creating Shared Value. Harvard Business Review, 89(12), pp.62-77.

Prahalad, C.K. \& Hart, S.L. (2002) The Fortune at the Bottom of the Pyramid. Strategy and Business, pp.54-54.

Robeyns, I. (2005) The Capability Approach: a theoratical Survey. Journal of Human development, 6(1), pp.93-114.

Sen, A. (1985) Commodities and Capabilities. Amsterdam: North Holland.

Sen, A. (1987) The Standard of Living. Cambridge: Cambridge University Press.

Sen, A. (1999) Development as Freedom. Oxford University Press.

Slavova, M., Venter, E. \& Baduza, G. (2011) Towards Applications of Capability Sensitive Design of Technologies. In Proceedings of the 12th International Conference on Social Implications of Computers in Developing Countries. Ocha Rios, Jamaica, 2011.

Stewart, F. (2005) Groups and Capabilities. Journal of Human Development, 6(2), pp.185-204.

Symon, G. and Casell, C. (2011) Qualitative Organizational Research. London: Sage.

The Monitor Group (2011) Job Creation Through Building the Field of Impact Sourcing.

[Online] Available at: http://www.rockefellerfoundation.org/news/publications/job-creationthrough-building-field [Accessed 25 November 2012].

Walby, S. (1990) Theorising Patriarchy. London: Basil Blackwell.

Walsham, G. (2006) Doing Interpretive Research. European Journal of Information Systems, 15(3), pp.320-30.

Woolcock, M. (2001) The place of social capital in understanding social and economic outcomes. ISUMA Canadian Journal of Policy Research, 2(1), pp.11-17 